\title{
An epidemic of diarrhoea in human neonates involving a reovirus-like agent and 'enteropathogenic' serotypes of Escherichia coli
}

\author{
R. F. BISHOP1, A. S. HEWSTONE, G. P. DAVIDSON, R. R. W. TOWNLEY, \\ I. H. HOLMES, AND B. J. RUCK
}

From the Department of Gastroenterology and the Department of Bacteriology, Royal Children's Hospital, Melbourne, and the Department of Microbiology, University of Melbourne, Melbourne, Australia 3052

SYNOPSIS During December 1974, an epidemic of diarrhoea occurred in the Royal Children's Hospital, Melbourne, in a ward caring for neonates with acute or chronic medical and surgical problems. Electron microscopy of diarrhoeal faeces revealed a reovirus-like particle ('duovirus' or 'rotavirus') known to cause acute enteritis in older children. This virus is considered to have been primarily involved in the aetiology of the epidemic. In addition, three 'enteropathogenic' serotypes of Escherichia coli were isolated from babies during the epidemic, but none produced enterotoxin when tested in ligated ileal loops of rabbits or in monolayers of Y1 adrenal cells. Further epidemics of neonatal diarrhoea must be studied using culture and electron microscopy of faeces to determine the relative importance of this virus and of $E$. coli in the aetiology of diarrhoea in this age-group.

Epidemics of diarrhoea occur from time to time in nurseries for the newborn and can result in severe illness and death in some infants.

In 1945, Bray implicated Escherichia coli in the aetiology of 'summer diarrhoea' in infants. Since then, a growing number of serotypes of $E$. coli have been associated with outbreaks of diarrhoea in newborn nurseries (Taylor, 1961). Proof of the aetiological role of these serotypes has usually relied on epidemiological evidence rather than on in vivo or in vitro tests to demonstrate enteropathogenicity. The belief has grown that $E$. coli should be considered an aetiologic agent in acute diarrhoeal disease when no other recognized pathogen can be isolated.

Recently, a reovirus-like particle (variously named 'duovirus' or 'rotavirus') has been recognized as a common worldwide cause of sporadic acute enteritis in young children (Davidson et al, 1975). Antigenically similar viruses cause diarrhoea in newborn calves (Mebus et al, 1971) and in infant mice (Cheever, 1956), but the importance of this virus in

${ }^{1}$ Requests for reprints should be addressed to: Dr R. F. Bishop, Department of Gastroenterology, Royal Children's Hospital, Melbourne, Victoria, Australia 3052

Received for publication 15 July 1975. the aetiology of epidemic diarrhoea in the human neonate is not yet known.

In December 1974, an outbreak of acute enteritis occurred in the neonatal ward of the Royal Children's Hospital, Melbourne, among babies with a variety of acute and chronic medical and surgical conditions. This paper describes our investigation of the aetiology of this outbreak using established microbiological techniques and electron microscopy of faecal extracts. The results suggest that the role of serotypically 'enteropathogenic' strains of $E$. coli in neonatal enteritis needs reappraisal.

\section{Material and Methods}

CLINICAL

At the time of the outbreak of diarrhoea, 32 infants ( 26 male, 6 female) aged from 1 day to 2 months (average age 15 days) were present in the neonatal ward. Twelve were in hospital for medical or surgical treatment of prematurity and its complications, 13 for congenital malformations, frequently of the gastrointestinal tract, four with congenital heart disease, and three for severe neonatal infection. Twenty-five were fed with artificial milk formula, five with expressed breast milk, and two by intravenous alimentation. 


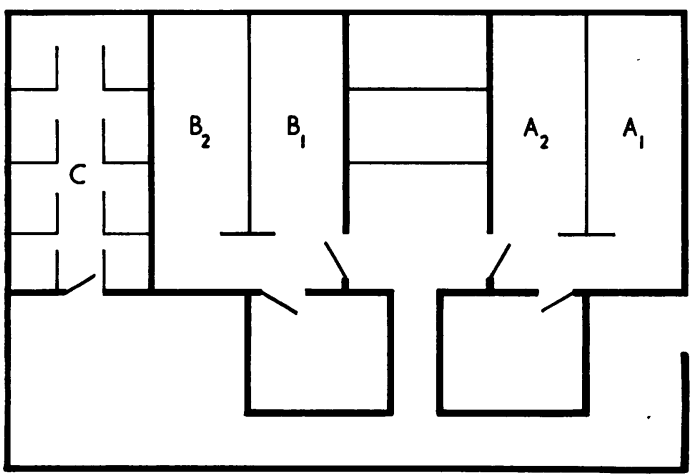

Fig 1 Neonatal ward, Royal Children's Hospital, Melbourne.

The 32 infants were housed in three separate nurseries, A, B, and $\mathrm{C}$, with separate nursing staff for each section (fig 1). At the time of the outbreak nursery A contained 18 babies with acute medical and surgical problems, nu sery $B$ contained 10 babies less severely ill, and nursery $\mathrm{C}$ contained babies in isolation areas.

During a period of 20 days, diarrhoea developed in 15 of the 32 babies, including all babies fed expressed breast milk. Symptoms of infection were mild, lasting one to three days in all but one baby. Sugar intolerance was diagnosed in 12 babies. Treatment included feeding with clear fluids for 12 to 24 hours, followed by glucose nutramigen (Mead Johnson).

The outbreak began when diarrhoea was observed in nursery $A$ in a baby aged 21 days recovering from surgery for oesophageal atresia. The baby had been in the ward for 16 days and had not been visited by relatives during that time. Six other babies occupying A1, and three babies in A2, developed diarrhoea during the next eight days.

Before the nature of the epidemic was recognized, babies had been moved from nursery A. Four days after transfer of a baby with inapparent infection to nursery B, diarrhoea developed in two of the nine babies already occupying this nursery and spread to three more babies during the next six days. No diarrhoea occurred in nursery $\mathbf{C}$ after transfer of infected babies, and no apparent spread of infection was seen after transfer of infected babies to two other wards in the hospital.

Eleven days after the outbreak began the neonatal ward was closed to new admissions for 18 days. No new cases of diarrhoea were observed after 16 days from onset of the outbreak.

COLLECTION OF SPECIMENS

Rectal swabs were obtained from 28 of the 32 babies on admission to the ward, from the index patient on the day of onset of diarrhoea, and four days later from 11 of the other babies in A1 and A2. Nine days after onset of the outbreak, rectal swabs were obtained from all 32 babies in nurseries A, B, and C. Thereafter daily rectal swabs were obtained from all babies while they remained in the neonatal ward.

Specimens of faeces for tissue culture and for examination by electron microscopy were collected from all babies on the ninth day of the epidemic. A second specimen was collected from babies who developed diarrhoea later.

\section{CULTURE TECHNIQUES}

Rectal swabs were inoculated on to horse blood agar, MacConkey agar, deoxycholate citrate agar, Salmonella Shigella medium, and in to selenite broth. Colonies of possible enteropathogens were identified biochemically. Serotypes of $E$. coli were identified by slide agglutination of six to 10 colonies with polyvalent and monovalent $E$. coli $\mathrm{OB}$ antisera (BBL). Positive results were confirmed using tube dilution tests with bacterial suspensions heated for one hour at $100^{\circ} \mathrm{C}$. Enterotoxin production by serotypes of $E$. coli isolated from symptomatic and asymptomatic infants was tested at least four times for each strain in ligated ileal loops of 12 to 16-weekold rabbits (Burrows and Musteikis, 1966), and in monolayers of Y1 adrenal cells (Donta et al, 1974).

Faecal specimens were inoculated into HeLa cells, primary monkey kidney cells, and human fetal fibroblasts for isolation of known viruses.

\section{ELECTRON MICROSCOPY}

Faeces were extracted by a technique of differential centrifugation designed to reveal the reovirus-like particle implicated in the aetiology of childhood enteritis (Bishop et al, 1974). Extracts of specimens were negatively stained with ammonium molybdate and examined with a Hitachi electron microscope at a magnification of $\times 30000$. Specimens were coded so the electron microscopist was unaware of their source.

\section{SEROLOGY}

Paired sera, collected at intervals of at least three weeks from three babies with symptoms of diarrhoea and from four asymptomatic babies, were titrated for antibodies to $E$. coli $\mathrm{O}_{111} \mathrm{~B}_{4}$ and to the reoviruslike agent. Antibodies to $E$. coli $\mathrm{O}_{111} \mathrm{~B}_{4}$ were estimated by indirect haemagglutination using $1 \%$ washed cells coated with $E$. coli $\mathrm{O}_{111} \mathbf{B}_{4}$. Antibodies to the reovirus-like agent were titrated by complement fixation using antigen prepared from faeces obtained from one of the symptomatic babies and known to contain abundant virus particles not already 


\begin{tabular}{lll}
\hline 'Enteropathogen' & \multicolumn{2}{l}{ Symptoms } \\
\cline { 2 - 3 } & Diarrhoea (15) & No Diarrhoea (17) \\
\hline Reovirus-like particle only & 2 & 1 \\
Reovirus-like particle + & 5 & 2 \\
E.coli $\mathrm{O}_{111} \mathrm{~B}_{4}$ & & \\
Reovirus-like particle & 1 & 0 \\
E.coli $\mathrm{O}_{125} \mathrm{~B}_{15}$ & 6 & 3 \\
E.coli $\mathrm{O}_{111} \mathrm{~B}_{4}$ & 1 & 1 \\
E.coli $\mathrm{O}_{125} \mathrm{~B}_{15}$ & 0 & 1 \\
E.coli $\mathrm{O}_{119} \mathrm{~B}_{14}$ & 0 & 9 \\
No pathogens isolated & &
\end{tabular}

Table I Enteropathogens in faeces from 32 infants in a neonatal ward during a 20-day outbreak of diarrhoea

\begin{tabular}{lllll}
\hline 'Enteropathogen' & \multirow{2}{*}{ Symptoms } & \multicolumn{3}{l}{ No. of Children in Nursery } \\
\cline { 3 - 5 } & & $A(18)$ & $B(10)$ & $C(4)$ \\
\hline E.coli $\mathrm{O}_{111} \mathrm{~B}_{4}$ & Diarrhoea & 9 & 2 & 0 \\
& No diarrhoea & 4 & 0 & 1 \\
Reovirus-like & Diarrhoea & 4 & 4 & 0 \\
particle & No diarrhoea & 2 & 1 & 0 \\
\hline
\end{tabular}

Table II Recovery of $\mathrm{E}$. coli $\mathrm{O}_{111} \mathrm{~B}_{4}$ and of reovirus-like particles from nurseries $A, B$ and $C$ in relation to diarrhoea

coated with antibody. Faeces were prepared as a $2 \%$ suspension in phosphate-buffered saline (Kapikian et al, 1974).

\section{Results}

Table I lists the results of bacterial culture and electron microscopy of faeces. In addition, echovirus 22 was isolated from five of 12 babies with diarrhoea, and from 12 of 17 asymptomatic babies.

Reovirus-like particles were observed either alone or associated with $E$. coli serotypes in eight of the 15 babies with diarrhoea, and in three asymptomatic babies. These particles were not observed in seven of the babies who developed diarrhoea, but six of these seven babies were asymptomatic at the time of faecal collection.

During the 20 days of the epidemic, E. coli $\mathrm{O}_{111} \mathrm{~B}_{4}{ }^{1}$ was grown from 11 of the 15 babies with diarrhoea, and from five of the 17 asymptomatic babies. All were identical biochemically and showed consistent antibiotic sensitivity patterns. E. coli $\mathrm{O}_{125} \mathrm{~B}_{15}$ was grown from two symptomatic babies and from one asymptomatic baby. E. coli $\mathrm{O}_{119} \mathrm{~B}_{14}$ was grown from one asymptomatic baby. None of the three serotypes produced enterotoxin when tested in vivo in rabbits and in vitro in adrenal cell culture.

Table II shows the distribution of E. coli $\mathrm{O}_{111} \mathrm{~B}_{4}$ and the reovirus-like particle between the three nurseries. E. coli $\mathrm{O}_{111} \mathrm{~B}_{4}$ was recovered much more

${ }^{1}$ Identified by Dr F. Ørskov as $\mathrm{O}_{111} \mathrm{H}_{21}$

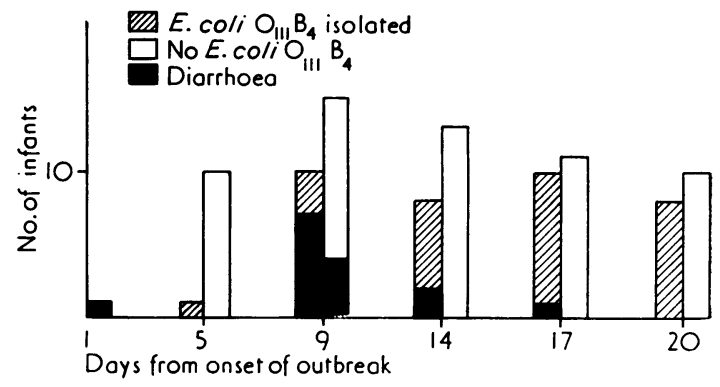

Fig 2 Occurrence of $\mathrm{E}$. coli $\mathrm{O}_{111} \mathrm{~B}_{4}$ in rectal swabs from neonates during an epidemic of diarrhoea.

frequently from babies housed in nursery $\mathrm{A}$ than in nursery $\mathrm{B}$, whereas the reovirus-like particle was located with approximately the same frequency in both nurseries.

Association of $E$. coli $\mathrm{O}_{111} \mathrm{~B}_{4}$ with symptoms of diarrhoea during the 20 days of the epidemic is shown in figure 2 . This organism was not identified in faeces obtained on admission to the ward from 28 babies. Acquisition of the strain occurred from five to 20 days after admission. It was isolated three days before onset of diarrhoea in two babies, coincident with onset in four babies, and seven days after onset in one baby. Relation of acquisition to onset of symptoms could not be determined in four babies. Seven babies continued to excrete $E$. coli $\mathrm{O}_{111} \mathrm{~B}_{4}$ for more than 10 days after recovery.

\section{SEROLOGY}

There was no rise in antibody titre to reovirus-like agent in three symptomatic babies shown to be infected with this virus. There was a fourfold rise in antibody titre in one asymptomatic baby infected with reovirus-like agent. One of the babies infected with $E$. coli $\mathrm{O}_{111} \mathrm{~B}_{4}$ showed a rise in antibody titre from $1 / 20$ to $1 / 80$. Titres from the other four babies remained at a level of $1 / 40$.

\section{Discussion}

This study describes an epidemic of diarrhoea among babies in the neonatal ward of the Royal Children's Hospital, Melbourne. The results of culture and of electron microscopy of faeces revealed several potential enteric pathogens, the two most important being a reovirus-like particle ('duovirus' or 'rotavirus') and $E$. coli $\mathrm{O}_{111} \mathrm{~B}_{4}$. A strain of echovirus 22 isolated from many symptomatic and asymptomatic babies was considered to be normal flora, since a three-year surveillance has shown that $86 \%$ of babies acquire this virus (or adenoviruses 9 and 15) within two weeks of admission to this ward (Jack, I., personal communication). 
We consider that the epidemic was primarily caused by infection with the reovirus-like agent even though it was not observed in all babies with diarrhoea. Failure to locate virus in these babies was due to imperfect timing of collection of faecal specimens. There can be no doubt that this virus causes acute enteritis in older children (Lancet, 1975). It has recently also been found associated with endemic and epidemic diarrhoea in nurseries for the newborn in five major obstetric hospitals in Melbourne (Cameron et al, 1975). Its association with enteritis in human neonates is not surprising, since enteritis is observed predominantly in the neonatal period in calves (Mebus et al, 1971) and mice (Cheever, 1956) infected with antigenically similar viruses.

During the epidemic, reovirus-like particles were seen in faeces from three babies with no symptoms of diarrhoea, one of whom showed seroconversion. This virus has previously been reported in two month-old babies with no symptomatic illness (Flewett et al, 1974). Passive protection by maternal antibody might be expected to mask symptoms of disease in the first weeks of life and is a possible explanation for the mildness of the diarrhoea observed in many babies.

We do not consider that the strain of $E$. coli $\mathrm{O}_{111} \mathrm{~B}_{4}$ isolated in this study was primarily implicated in the aetiology of the epidemic. Isolation from rectal swabs did not correlate well with the presence and absence of symptomatic illness, and none of the strains produced enterotoxin despite repeated testing. Isolation of two other 'enteropathogenic' serotypes of $E$. coli is not unique (Ørskov, F., personal communication) and reinforces our belief that the reovirus-like particle was the aetiological agent in this epidemic. It is possible that colonization by $E$. coli was a secondary result of infection with the reovirus-like agent, as has been observed in calves (Mebus et al, 1971).

The results described in this paper emphasize that strains of $E$. coli isolated from sporadic or epidemic diarrhoea should not be assumed to be enteropathogenic on the basis of serotype alone. Many similar outbreaks must be studied in order to assess the relative importance of the reovirus-like agent and $E$. coli in the aetiology of diarrhoea in human neonates throughout the world. It seems likely that the reovirus-like agent will be relatively more common in countries with high standards of community hygiene than in poorer communities (Schoub et al, 1975). The possibility that both pathogens act synergistically to produce severe disease remains to be elucidated.

We are very grateful to Dr John Craven, of the Department of Agriculture Veterinary Research Laboratory, Melbourne, and to Mr Norbert Ryan and Dr Richard Luke, of the Department of Agriculture, Latrobe University, Melbourne, for enterotoxin assays. We thank the medical and nursing staff of ward $10 \mathrm{~W}$ for their co-operation; Mr Max Murray, Miss Anneke Veenstra, and Mrs Wendy Henry for their technical assistance; and Mrs Anne Peace for secretarial help. The work was supported by the Felton Bequest (RFB), the Lady Latham Research Fellowship of the Royal Children's Hospital Research Foundation (GPD), and the National Health and Medical Research Council of Australia (IHH, BJR).

\section{References}

Bishop, R. F., Davidson, G. P., Holmes, I. H., and Ruck, B. J. (1974). Detection of a new virus by electron microscopy of faecal extracts from children with acute gastroenteritis. Lancet, 1, 149-151.

Bray, J. (1945). Isolation of antigenically homogeneous strains of Bact. coli neopolitanum from summer diarrhoea of infants. J. Path. Bact., 57, 239-247.

Burrows, W. and Musteikis, G. M. (1966). Cholera infection and toxin in the rabbit ileal loop. J. infect. Dis., 116, 183-190.

Cameron, D. J. S., Bishop, R. F., Davidson, G. P., Townley, R. R. W., Holmes, I. H., and Ruck, B. J. (1975). New virus associated with diarrhoea in neonates. Med. J. Aust. (In press).

Cheever, F. S. (1956). Epidemic diarrheal disease of suckling mice. Ann. N. Y. Acad. Sci., 66, 196-203.

Davidson, G. P., Bishop, R. F., Townley R. R. W., Holmes, I. H., and Ruck, B. J. (1975). Importance of a new virus in acute sporadic enteritis in children. Lancet, 1, 242-244.

Donta, S. T., Moon, H. W., and Whipp, S. C. (1974). Detection of heat-labile Escherichia coli enterotoxin with the use of adrenal cells in tissue culture. Science, 183, 334-336.

Flewett, T. H., Davies, H., Bryden, A. S., and Robertson, M. J. (1974). Acute gastroenteritis associated with reoviruslike particles. J. clin. Path., 27, 608-614.

Kapikian, A. Z., Kim, H. W., Wyatt, R. G., Rodriguez, W. J., Ross, S., Cline, W. L., Parrott, R. H., and Chanock, R. M. (1974). Reovirus-like agent in stools: association with infantile diarrhoea and development of serologic tests. Science, 185, 1049-1052.

Lancet (1975). Rotaviruses of man and animals. (Leading article). Lancet, 1, 257-259.

Mebus, C. A., Stair, E. L., Underdahl, N. R., and Twiehaus, M. J. (1971). Pathology of neonatal calf diarrhea induced by a Reo-like virus. Vet. Path., 8, 490-505.

Schoub, B. D., Koornhof, H. J., Lecatsas, G., Prozesky, O. W., Freiman, I., Hartman, E., and Kassel, H. (1975). Viruses in acute summer gastroenteritis in black infants. (Letter.) Lancet, 1, 1093-1094.

Taylor, J. (1961). Host specificity and enteropathogenicity of Escherichia coli. J. appl. Bact., 24, 316-325. 